\title{
Review: Günther Witzany (2007) The logos of the bios 2. Helsinki: Umweb
}

\author{
Seán Ó Nualláin
}

Molecular and Cell Biology (MCB), UC Berkeley,

Berkeley, Ca 94705, USA;

Phone +15106426202; sonual@stanford.edu

\section{Preliminary note}

Previously (TripleC 5(1): 1-3, 2007), the writer reviewed volume 1 of this series. Several of the comments therein remain valid; Witzany's attempt to create a new environmentally sound paradigm for biology is a worthwhile project, though there is always a problem deriving "ought" from "is" (or morality from life, as Kant put it); Guenther needs to secure his grasp on linguistics; finally, there are none of the egregious mistakes about the number of human genes as in volume 1 . Since much of the previous critique remains valid, I will review this book under a different set of categories. While he describes it (9; unless otherwise stated, page numbers are from his book) as a practical application of "a pragmatic philosophy of biology", its major interest may be wholly other. In that same vein, given that it is essentially a collection of recently published articles, thematic unity might be more difficult than in a monograph. That said, there are four introductory chapters where his tripartite biosemiotic schema is appropriately applied to plant, fungal, coral, and bacterial communication.

The context of his books is the dearth of theory, and the negative consequences, in some of the major subfields within biology. It manifests itself in evolution, where the absence of theory and metatheory has led to entrenchment in the opposing camps of neo-Darwinism and intelligent design (which, in turn, was recently outed as creationism). In genetics, the much-hyped human genome project has led to frustration, as the absurd claims made by its proponents have fallen massively short of the reality, and as re- searchers desperately seek for new paradigms in network theory, language, and so on. The "silver bullet" ethos of the human genome project exacerbated the destructive over-emphasis on curative, versus preventative medicine. In neuroscience, the very salience of synaptic transmission has been questioned by neural resonance on the one hand, and extra-synaptic bursting on the other extreme. In the meanwhile, the failure to explain even the elements of human symbolic behavior with respect to neural event has led to crises within cognitive science, and a vacuum in consciousness theory. Finally, there are the twin paradoxes that reductionist analysis of life loses life itself as it plunges to the nano level and beyond; finally, the issue of where the program lies for life.

While this is quite an agenda, it is fair to say that Guenther does not shy at the challenge. Inevitably, of course, he falls short, as all of us will. What follows is a set of specific criticisms of specific points; both books are essential reading for anyone concerned with humanity's proper place in the biosphere.

\section{The levels of language}

While obviously aware of Peirce (212), Guenther is refreshingly free of the Peircean dogma that holds biosemiotics somewhat in thrall, and attempts analysis in terms of conventional linguistics. So we can agree that syntax deals with the rule-governed combination of symbols and, roughly, that pragmatics deals with issues that are context-sensitive; he diverges somewhat from conventional usage in his contention that 
semantics refers to content-sensitive issues. One of the things we learned from a half-century of work in computational linguistics was that it was useful to distinguish context-specific from context-general semantic primitives (see Ó Nualláin (2003), chapter 3). Similarly, Guenther has yet fully to digest JL Austin (ibid.) and continues to use the word "illocutionary" for situations where "perlocutionary" is appropriate.

This is actually quite a big deal as much hinges on the notion that "life is structured linguistically and organised communicatively" (9); it is in fact the essence of the pragmatic philosophy of biology. This tenet is expanded upon later (14) with the statement that living nature is related essentially to signals, syntax, and pragmatics. Echoing Wittgenstein on the distinction between the older and more streamlined parts of cities, Guenther goes so far as to say (154) that coding DNA resembles scientific language, and non-coding, perhaps, everyday discourse. So there is a program for life in this book; immersion in complexity theory and its treatment of the relationship between organism and environment is, in my opinion mistakenly, eschewed.

Guenther's analysis here is courageous and imaginative; yet it is fatally flawed. This becomes particularly the case when he baldly states in a paragraph heading (12) that "context determines meaning". Context is of course a factor; so is the lexicon, syntax, and semantics. Indeed, if context is restricted, syntax can take over several of the roles of semantics (Ó Nualláin and Richard Strohman, 2007, 258). So we need to split this word "context" into two related concepts; the particular domain being processed, and the epistemological or biochemical degrees of freedom are the restriction of the context. Then, and only then, can we begin to discuss how context interacts with the lexicon (be it genetic or linguistic), syntax, and semantics (ibid.)

\section{Mitwelt versus Umwelt}

Guenther is rightly concerned that we replace the Umwelt with a Mitwelt, echoing Heidegger's concept translated into English simply as "care". Mitwelt he defines (207) as a term for "the investigation of all rule-governed sign-mediated interactions of organisms". Perhaps mistakenly, he insists that we regard biology as sign-based rather than simply natural law-based. In the famous Villa Serbelloni sessions headed by Conrad Waddington, the conclusion from the Waddington group tended more in the direction of emphasizing hierarchy to language, and indeed later researchers like Strohman propose that the concept of law itself is attenuated in biology, and that this needs to be rectified.
Chapter 7, explicitly dealing with Umwelt and Mitwelt, features immersion in the deepest intellectual waters to date (212-213). In a prelude (209), the concept of Umwelt is critiqued for its inability to transcend mere natural law to consider rule-governed sign-mediated interactions. However, Guenther is going for very big game indeed; he wishes to establish that "semiotics as well as biosemiotics are really social sciences" (213). The argument is straightforward; biological activity, including semiosis, is communicative and intersubjective; therefore the social is primary.

This will never do. For a start, it is a category error; social science analyses processes like politics and business, which have sui generis emergent laws. Secondly, much of our cognition and symbolic behavior as humans in fact makes clear subject/object dichotomies in practice. Elsewhere (in press), this writer argues that the Cartesian split is indeed an egregious one, but that, pace Heidegger, Merleau-Ponty et al., there is such a thing as an autonomous hman subject. The "Da-sein" of the former and "esprit incarnee" of the latter need to be supplemented with the capacity for insulation from the world, perhaps a cognitive correlate of the emergence of cells.

It behooves Guenther to consider this as a complement to the pointed attack (213) on the "solus ipse subject of knowledge of Descartes and Kant". Here, as elsewhere, one looks forward to Volume 3. In the meantime (230-231), he posits consequences from his position for a radically altered science of genetic engineering, the avoidance of "scientific, medical and even political fallacies" in epidemiology, a hermeneutic approach to biology, and inveighing against determinism.

\section{The rehabilitation of viruses}

Perhaps the strongest chapter of the book is chapter 5, the "natural genome editing competences of viruses". Pp. 157-164 read like an impassioned rehabilitation of viruses; indeed, $P$. 181 catalogues the achievements of viral gene editing, including RNA/DNA, gene repair, methylation, and both the adaptive and innate immune systems. Gene-editing features also in volume 1; this adaptation of the work of Villareal and others is thought-provoking.

Elsewhere (220), Guenther refers to his previous work on the Gemetacode, the exploitation of socalled "junk" DNA in gene regulation. Herein perhaps lie his true strengths; however, the notion of meta codes in computational linguistics led to something of a dead end, propinquant to that of the Tractatus Wittgenstein (Ó Nualláin and Richard Strohman, 2007, 256). Even if 
successful, it would just have led to a search for meta meta codes.

\section{Conclusion}

It may be clear by now that this reviewer greatly admires the range and energy of the book, but believes it misguided in thrust. To repeat a point from the critique of volume 1 , it is possible to be just as rigid toward and destructive of a biosphere considered as linguistic as one considered as subject to lower-order natural law. Secondly, it fails to take account of biochemistry considered as a complement to descriptions couched in the terms of gene expression. The consequences of this can be massive; for example, spina bifida in the progeny can be prevented simply by the mother's taking folic acid during pregnancy. No amount of gene expression work using our current laboratory armory would reveal this. In fact, a catalogue of these biochemical pathways needs to be juxtaposed with gene expression inventories for any progress in this area to be established. There is an intriguing analogy here; Vygotsky's radical notion that "thought" and "language" come from distinct evolutionary sources and are synthesised only in humans. Thus arises the difficulty with natural language processing by computers; the correlate for epigenetics may be a myriad context-specific interactions of gene and metabolic context (Ó Nualláin and Richard Strohman, 2007). Tentatively, one might propose that the HGP discovered the $2 \%$ to $4 \%$ or so of geneexpression mechanisms that are contextindependent. All others mechanisms change for with the metabolic context.

Finally, we undoubtedly urgently need a new vocabulary and set of emotional cathexes for our relationship to the biosphere, one free of nature as instrument (Ó Nualláin 2004). The book argues that we need a concept of a Mitwelt, the notion that we are intimately connected with nature. Yet even that notion is an objective third person judgement; we cannot avoid being neoCartesians, if only momentarily. What we can do is trust ourselves to build educational institutions that introduce students into a reverence for life, while also imparting both theoretical and applied knowledge. Imposition of a Weltanschauung, whether based on Roman Catholicism or semiosis, is a fortiori a controversial political act. We can teach appreciation of nature and of the cosmos as surely as we can produce a good arts education; yet words alone, independent of contact with a teacher, will rarely suffice. Deriving morality from life, ought from is, remains unsolvable as a general problem.

\section{References}

Ó Nualláin, Seán (2003) The Search for Mind. Third edition. Exeter. England.

Ó Nualláin, Seán (2004) Being Human: The Search for Order. Second edition. Exeter. England.

Ó Nualláin, Seán (forthcoming) Neural correlates of consciousness of what? Target article, New ideas in psychology.

Ó Nualláin, Seán and Richard Strohman (2007) Genome and natural language: How far can the analogy be extended? In: Witzany (ed.) Proceedings of Biosemiotics 2006. Tartu University Press. Finland. Umweb. pp 249-260 